PNL-6996

UC-507

$6 c$

\title{
DOE Radiological Calibrations Intercomparison Program: Results of Fiscal Year 1988
}

F. M. Cummings

J. C. McDonald

M. K. Murphy

August 1989

Prepared for

the U.S. Department of Energy

Assistant Secretary for

Environment, Safety, and Health

under Contract DE-AC06-76RLO 1830

Pacific Northwest Laboratory

Operated for the U.S. Department of Energy

by Battelle Memorial Institute 


\title{
DISCLAIMER
}

This program was prepared as an account of work sponsored by an agency of the United States Government. Neither the United States Government nor any agency thereof, nor Battelle Memorial institute, nor any or their employees, makes any waranty, expressed or implied, or assumes any legal liability or responsibility for the accuracy, completeness, or usefulness of any information, apparatus, product, or process disclosed, or represents that its use would not infringe privately owned rights. Reference herein to any specific commercial product, process, or service by trade name, trademark, manufacturer, or otherwise, does not necessarily constitute or imply its endorsement, recommendation, or favoring by the United States Government of any agency thereof, or Battelle Memorial Institute. The views and opinions of authors expressed herein do not necessarily state or reflect those of the United States Government or any agency thereot.

\author{
PACIFIC NORTHWEST LABORATORY \\ operated by \\ BATTELLE MEMORIAL INSTITUTE \\ for the \\ UNITED STATES DEPARTMENT OF ENERGY \\ under Contract DE-AC06-76RLO 1830
}

Printed in the United States of America

Available to DOE and DOE contractors from the

Office of Scientific and Technical Information, P.O. Box 62, Oak Ridge, TN 37831; prices available from $\{615)$ 576-8401. FTS 626-8401.

Available to the public from the National Technical Information Service, U.S. Department of Commerce, 5285 Port Royal Rd., Springfield, VA 22161.

NTIS Price Codes, Microfiche A01

\begin{tabular}{|c|c|}
\hline \multicolumn{2}{|c|}{ Printed Copy } \\
\hline Pages & $\begin{array}{l}\text { Price } \\
\text { Codes }\end{array}$ \\
\hline$\overline{001-025}$ & $\overline{\mathrm{A} 02}$ \\
\hline $026-050$ & $\mathrm{~A} 03$ \\
\hline $051-075$ & A04 \\
\hline 076-100 & $\mathrm{A} 05$ \\
\hline 101.125 & $A 06$ \\
\hline $126-150$ & $\mathrm{~A} 07$ \\
\hline $151-175$ & $\mathrm{~A} 0 \mathrm{~B}$ \\
\hline $176-200$ & A09 \\
\hline $201-225$ & A10 \\
\hline $226-250$ & A11 \\
\hline $251-275$ & $\mathrm{~A} 12$ \\
\hline $276-300$ & $\mathrm{~A} 13$ \\
\hline
\end{tabular}


F. M. Cummings (a)

J. C. McDonald

M. K. Murphy

August 1989

Prepared for

the U.S. Department of Energy Assistant Secretary for Environment, Safety, and Health under Contract DE-AC06-76RLO 1830

Pacific Northwest Laboratory Richland, Washington 99352

(a) Current address: U.S. Department of Energy Idaho Operations office 785 DOE Place Idaho Falls, ID 83402-4149 


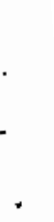




\section{FOREWORD}

The radiological calibration program is fundamental to radiation protection. The quality of a radiation protection program depends on maintaining standards for radiological calibration that are directly traceable to national standards and for which measurements of verification may be routinely and precisely performed. The U.S. Department of Energy (DOE) Intercomparison Program, developed by the DOE Office of Nuclear Safety, has a goal to improve accuracy and precision in the measurement of radiological standards. Performing the intercomparison measurements helps identify areas requiring further attention by the participating laboratories, and communication is increased among individuals responsible for maintaining radiological standards. To the individual participant, the intercomparison program provides the opportunity to gain in understanding particular irradiation sources and facilities and to test transfer techniques not usually available in the participant's laboratory.

The measurement process allows the use of either state-of-the-art calibration equipment, which may be different from that used at the participant's laboratory, or a secondary standard set of beta sources described and specified in the International Standardization Organization (ISO) standard for beta dosimetry, ISO 6980 (1984).

Participation in this program by all DOE laboratories maintaining radiological standards is both welcomed and encouraged. We hope that the publication of the present and future annual reports will serve to both identify and maximize the benefits of the program. 


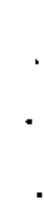




\section{$\underline{\text { SUMPMARY }}$}

Calibration measurements for personnel dosimetry purposes must be both accurate and consistent with national standards. In order to satisfy these requirements, the following methods are usually employed. In one case, a radiation source is sent to the National Institute of Standards and Technology (NIST), formerly the National Bureau of Standards, for calibration and is returned to the laboratory to be used as a local standard. Another method involves the calibration of an instrument, such as an ionization chamber, by NIST. After calibration, this instrument is then used to measure the exposure rate delivered by radiation sources at the laboratory. Such calibrations by NIST are essential, but they do not provide a complete check on the quality of the calibrations that are carried out by the individual laboratory. Additional measurements are necessary to assure the quality of such measurements. When laboratory staff are asked to carry out measurements with calibrated instruments and report results for evaluation, they are participating in a measurement quality assurance (MOA) program. Such a program tests not only the quality of the equipment but also the ability of the staff to correctly use and interpret the results obtained with the equipment. The NIST operates an MQA program with a selected number of calibration laboratories. Pacific Northwest Laboratory (PNL) participates in this MOA program even though NIST tests only x-ray and gamma-ray measurements. The U.S. Department of Energy (DOE) intercomparison program was designed specifically to include $x$-ray, gamma-ray, beta, and neutron calibrations for personnel dosimetry purposes. This program serves a need that is not being met by NIST, and it provides documentation of the accuracy and uniformity of the radiological calibrations carried out in DOE facilities. 


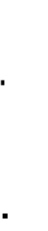

. 


\section{ACKNOWLEDGMENTS}

The authors wish to thank J. M. Selby and G. H. R. Endres for reviewing this report and for their helpful suggestions. We also thank Nora Buel for editing the report and Marianna Cross for typing it. 


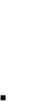

. 


\section{CONTENTS}

FOREWORD ...................... i i i

SUMMARY ...................... v

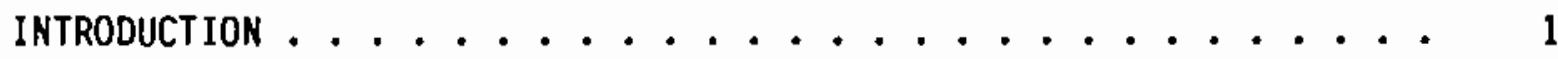

INTERCOMPARISON PROGRAM OPERATION .............. 3

EQUIPMENT DESCRIPTION ................. 5

INSTRUMENT SET ........................ 5

Electrometer ................... 5

Thin-Kalled Ionization Chamber for Photon Measurements . . 7

Tissue Equivalent Ionization Chamber for Neutron

Measurements ............... 8

Geiger-Mueller Counter............ 8

Extrapolation Ionization Chamber for Beta Measurements . 8

Scaler/Ratemeter.................. 9

Battery High-Voltage Power Supply .......... 9

Charge Checker................. 9

Procedures ..................... g

SECONDARY STANDARD BETA SOURCE SET ........... 10

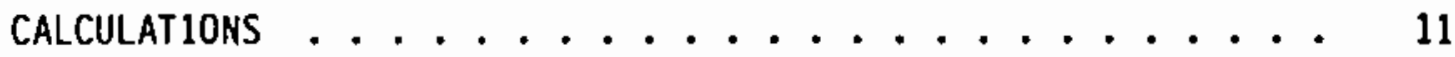

Instruments ..................... 12

Beta Sources.................. 15

MEASUREMENT RESULTS . . . . . . . . . . . . 17

PROGRAM PROBLEMS AND IMPROVEMENTS ............... 21

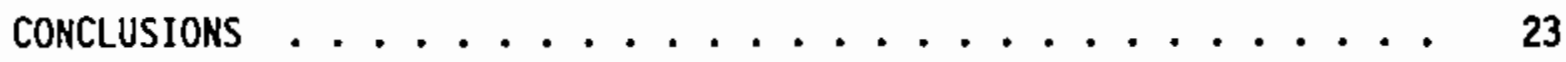

REFERENCES ............................ 25 


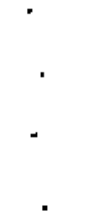




\section{FIGURES}

1 DOE Intercomparison Program Instrument Set . . . . . . . 6

2 The Keithley Electrometer, Front Panel ........... 7

3 DOE Intercomparison Program Secondary Standard

Beta Source Set . . . . . . . . . . . . . . . . . 11

\section{TABLES}

1 Equipment Contained in the Intercomparison Instrument Set . . 6

2 Parameters Used to Calculate the Absorbed Oose from the DOE Intercomparison Beta Sources ......... 16

3 Parameters Used to Calculate the Air Density Corrections, $K_{A}, D=D_{0}\left(1+a x+b x^{2}\right)$ and $x=1-\rho_{1} \ldots \ldots$

4 Summary of Intercomparison Results Using the Air Equivalent Ionization Chamber . . . . . . . . . . 18

5 Sumary of Intercomparison Results for Neutron Kerma Rate Measurements ................... 18

6 Summary of Intercomparison Measurements Using the FWT Extrapolation Chamber ................ 19

7 Summary of Intercomparison Measurements on X-ray Sources . . . 19 


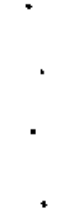




\section{INTRODUCTION}

During the fiscal years (FY) 1984 and 1985, the Pacific Morthwest Laboratory (PNL) (a) conducted a study to evaluate the feasibility of operating a routine program for the intercomparison of radiological calibrations performed at U.S. Department of Energy (DOE) facilities. The objectives of the intercomparison program are to 1) provide standard measurement techniques that allow DOE laboratories to assess and improve the accuracy of radiological calibration sources, 2) provide a database for recommending improvements in calibration techniques and units generally applicable to all DOE facilities, and 3) provide a forum addressing problems and potential problems related to radiological calibrations.

To meet the objectives, a program under the DOE Laboratory Accreditation Program (DOELAP), was initiated during FY 1986 to routinely compare radiological calibrations. The program is managed and operated by PKL. A set of intercomparison instruments was made available to DOE laboratories on a monthly basis, and one secondary beta source set was made available to DOE laboratories on a bimonthly basis. Participants in the program used the instruments to perform dose or exposure measurements on their calibration sources, or they used the beta source to irradiate the instruments that calibrate their standards. The results of the measurements were forwarded to PNL for tabulating and comparing to calibration values established by PNL for the various instruments and beta sources. Participation by the DOE laboratories was voluntary; submission of measurement results was also voluntary, even though strict confidentiality was maintained regarding the originator of the results.

To compare measurements from a wide variety of sources, four instruments were selected for inclusion in the instrument set. The four instruments and their respective uses are 1) a thin-walled ion chamber with build-up cap to measure the exposure rate from $x$-ray and gamma-ray sources, 2) a tissue equivalent ionization chamber to measure the absorbed dose rate from neutron sources, 3) a Geiger-Mueller (GM) counter to estimate the absorbed dose rate

\footnotetext{
(a) PNL is operated for the U.S. Department of Energy by Battelle Memorial
} Institute under Contract DE-ACO6-76RLO 1830. 
for photons in mixed neutron/gamma fields, and 4) an extrapolation ionization chamber to measure the absorbed dose rate from beta sources.

In addition, a set of beta sources including a 2-mCi (74-MBq) $90 \mathrm{Sr} / 90 \mathrm{Y}$ source, a $0.5-\mathrm{mCi}$ (18.5-MBq) 204Tl source, and a 14.5-mCi (536.5-MBq) $147 \mathrm{Pm}_{\mathrm{m}}$ source was provided. The set also included an irradiation jig and a shutter with a controller/timer.

Instrument and source sets were scheduled for distribution to participants based on availability. There were two instrument sets, and scheduling was staggered such that one set was available each month. The source set was available on a bimonthly basis.

Participants performed the desired measurements and irradiations, and returned the sets and results to PNL. The instruments were operationally checked and sent to the next participant. The measurement results were compared to PNL values and reported to each participant. This annual report summarizes the operation, results, problems, and improvements in the program.

The DOE benefits from the operation of the program in many ways. Sone of these benefits include:

- The accuracy and credibility of radiological calibration are improved by frequent measurement and intercomparison.

- Common problems of a general nature are identified, allowing a DOE-wide approach in solving problems related to radiological calibrations.

- A radiological calibration workshop is planned to be held once every 2 years. This provides a forum in which to address the impact of proposed regulations on calibrations, such as changes in the neutron quality factor and changes resulting from the impact of calibrations on regulations, e.g., the DOELAP performance results.

- The results and conclusions of this project directly support the DOELAP operational program and certain DOELAP research tasks.

This report presents the FY 1988 results of the radiological calibrations intercomparison program. The intercomparison operation is discussed, and the equipment is described, particularly the instrument set, the beta source set, and relevant calculations. Solutions to problems and improvements in the program are suggested, and conclusions are then introduced. 


\section{INTERCOMPARISON PROGRAM OPERATION}

The intercomparison program makes the instrument sets and beta source set available to the greatest number of participants possible during the fiscal year. The operation of the program is described below in chronological sequence.

1. An invitation to participate in the intercomparison is sent annually to those people at DOE laboratories who are primarily involved in performing or managing radiological calibrations. The invitation contains a short history of the intercomparison and a participation request form.

2. When a participation request form is received from a participant, the requested instrument set or beta set is scheduled as specified on the form. If a particular intercomparison set is unavailable at the requested time, the participant is notified in order to reschedule the intercomparison set.

3. Letters are sent to participants verifying the scheduled use of the intercomparison sets. The expected arrival of the set will occur during the second week of the scheduled month of participation.

4. The participant uses the intercomparison set on the calibration sources of his choice. At the conclusion of the measurements or irradiations, the set is returned to PNL so that its expected arrival occurs during the last week of the month after it was sent. Thus, the length of time a participant has the intercomparison set is aiways greater than 4 weeks.

5. Results of the measurements or irradiations are reported to PNL where those results are compared to reference values. The comparisons and the calculational methods are normally reported back to each participant within 6 weeks of the time their results were reported to PNL.

At any time during the sequence, the participant may decide that the results are suspect and should not be reported. Because participation is voluntary, the use of the reported data has been left in the control of the participant. All results, however, are strictly confidential between the PNL intercomparison program manager and the participating laboratory. 


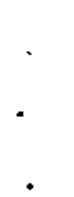




\section{EQUIPMENT DESCRIPTION}

The equipment used in the DOE Radiological Calibrations Intercomparison Program includes two complete sets of intercomparison instruments and one set of secondary standard beta sources. The components of each set are described in the following sections.

\section{INSTRUMENT SET}

The instruments used in the intercomparison were the same as those used for the pilot intercomparison program. These particular instruments were chosen for maximum flexibility of dose measurement from a variety of radiological sources, for their precision and stability, and for their simplicity of use and familiarity to the participants.

The specific pieces of equipment contained in each instrument set are listed in Table 1. The intended purpose of each piece of equipment is also provided in Table 1.

The chambers are calibrated using $137 \mathrm{Cs}$ in the PNL calibration facility. The exposure rates of the $137 \mathrm{Cs}$ source are traceable to the National Institute of Standards and Technology (NIST) by means of transfer standards (ionization chambers). The electrometer is calibrated using a picoampere source, which is traceable to NIST from the Hanford Engineering Development Laboratory Calibration Program. The instruments are shown in Figure 1, and a description of each instrument is provided below.

\section{Electrometer}

The electrometer is a Keithley Model 614 multifunction meter(a) capable of measuring integral charge between $10^{-8}$ and 10-11 coulombs (C) and voltages between $10^{-4}$ and 20 volts $(v)$. It can operate on $110 \mathrm{~V}(\mathrm{ac})$ or on its integral battery pack. The display is $4-1 / 2$ digits.

The input/output connector is a triaxial connector. In addition, a triaxial-to-coaxial (triax-to-coax) adapter is provided, allowing the user to use low-noise coaxial signal cables for the ionization chambers. A 75-ft coaxial signal cable is also supplied in the instrument set.

(a) Keithley Instruments, Cleveland, Ohio. 
TABLE 1. Equipment Contained in the Intercomparison Instrument Set

Piece of Equipment

Electrometer

Thin-walled ion chamber

Tissue equivalent ion chamber

Extrapolation ion chamber

Geiger-Mueller (GM) counter

Scaler/ratemeter

Battery high-voltage power supply

Charge checker
Intended Purpose

Measure and record integral charge from ionization chamber measurements

Measure exposure from photon calibration sources

Measure total kerma from neutron calibration sources

Measure the dose rate from beta calibration sources at $7 \mathrm{mg} / \mathrm{cm}^{2}$

Measure the component of dose resulting from photons created by a neutron calibration source

Record integral pulses from the GM counter and supply high voltage to the GM counter

Provide a stable bias voltage in $50 \mathrm{~V}$ steps from 0 to $\$ 300 \mathrm{~V}$ for use with ionization chambers

Provide a stable charge with which to check the electrometer operation

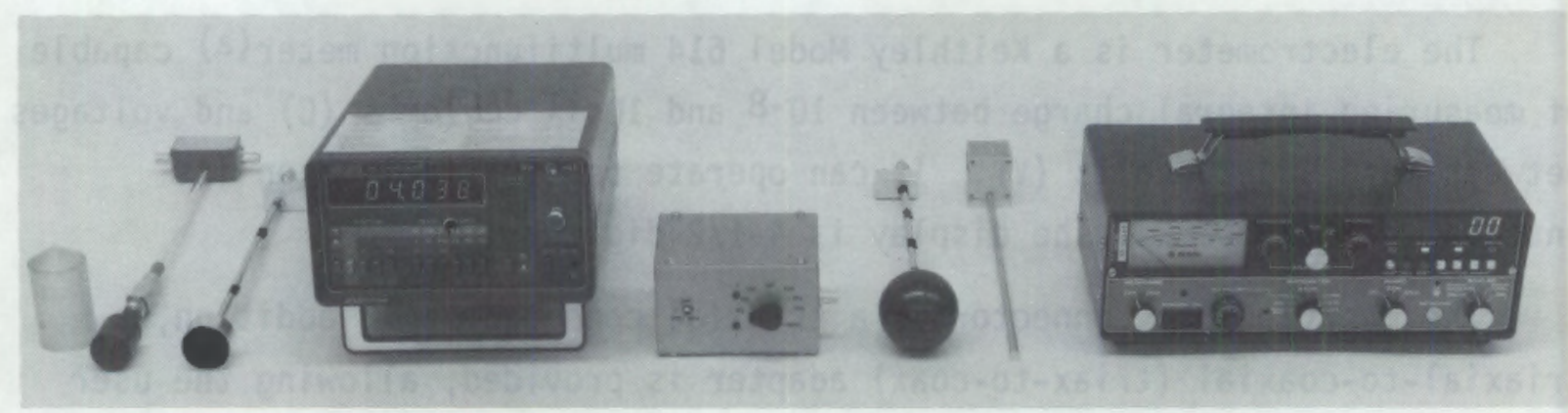

FIGURE 1. DOE Intercomparison Program Instrument Set 
The front panel of the Keithley electrometer is illustrated in Figure 2. The electrometer has been modified by the inclusion of a "run/hold" switch that "freezes" the display and allows timed measurements.

Thin-Walled Ionization Chamber for Photon Measurements

The ionization chamber chosen for photon measurements is a Capintec Model PM-30. (a) The chamber is constructed of air equivalent conducting plastic and has an active volume of $28 \mathrm{~cm}^{3}$. The response of the instrument for measuring exposure is nearly independent of the energy of the incident photons from $20 \mathrm{keV}$ to a few MeV. The useful dose range is approximately $100 \mathrm{mR} / \mathrm{h}$ to $10 \mathrm{R} / \mathrm{min}$. A Lucite buildup cap is provided so the chamber can be used for high-energy photons $(137 \mathrm{Cs}$ and $60 \mathrm{Co})$. Without the buildup cap, the chamber may also be used to measure exposure rates from $x$-ray beams. The connector is a triaxial-BNC-type that connects to a shop-built cable splitter. The connections on the cable splitter are BNC for the signal and MHV for the high voltage.

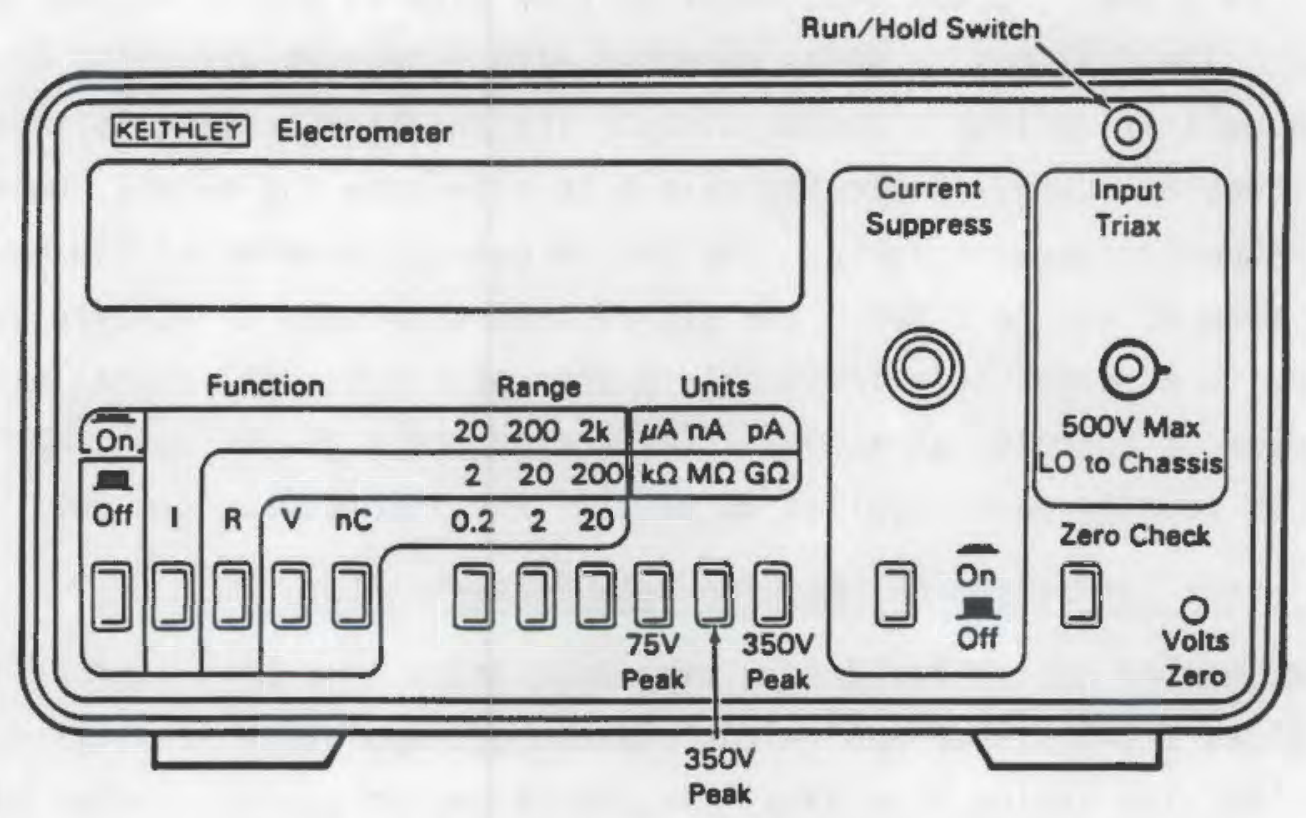

FIGURE 2. The Keithley Electrometer, Front Panel

(a) Capintec, Inc., Montvale, New Jersey.

- Trademark of the E. I. duPont de Nemours \& Company, Wilmington, Delaware. 
Tissue Equivalent Ionization Chamber for Neutron Measurements

The ionization chamber chosen for neutron measurements is a Far West Technology (FWT) (a) Model IC-80 tissue equivalent ionization chamber (TEIC). The $80-\mathrm{cm}^{3}$ spherical chamber is constructed of A-150 tissue equivalent plastic and is usually operated with ambient air as the fill gas, rather than tissue equivalent counting gas. The signal output connector is a BNCtype, and the high-voltage connector is an MHV-type. The chamber is operated using $300 \mathrm{~V}$ high voltage. The signal is directed to the electrometer by means of a low-noise coaxial signal cable and a coax-to-triax adapter. The instrument is used in conjunction with a GM counter for neutron measurements. The ionization chamber measures total kerma. The GM counter, because of its low sensitivity to neutrons, is used to measure the kerma from photons. Geiger-Mueller Counter

The GM counter chosen to measure the photon contribution of kerma in a neutron field is an FWT model GM-2 energy-compensated GM counter. (a) The detector is a small, 0.48-cm-diameter GM tube with an active volume of $0.12 \mathrm{~cm}^{3}$. The fill gas is neon, quenched with a halogen-quenching agent. The tube wall is an iron chromium alloy. The detector housing is aluminum and includes an energy-flattening shield to eliminate the normal low-energy photon response characteristic. The photon energy response of the GM counter is $\pm 10 \%$ from $70 \mathrm{keV}$ to $2 \mathrm{MeV}$. The signal output through a BNC-type connector is routed to a read-out device (scaler) through the coaxial signal cable. The counter is operated at $+500 \mathrm{~V}$. The scaler and high-voltage power supply for the GM counter were supplied as part of the intercomparison set.

Extrapolation Ionization Chamber for Beta Measurements

The chamber chosen for determining dose rates from beta sources is an FWT Model EIC-1 tissue equivalent plastic extrapolation ionization chamber. (b) The device is a parallel-plate-type ionization chamber with a continuously variable volume from approximately 0.1 to $1.4 \mathrm{~cm}^{3}$. The front entry window has a density thickness of $6.9 \mathrm{mg} / \mathrm{cm}^{2}$. The collecting electrode was modified by the manufacturer from a $1-\mathrm{cm}$ to a $2-\mathrm{cm}$ diameter to increase the sensitivity. The output is routed through a BNC connector to the

(a) Far West Technology, Goleta, California.

(b) Far West Technology, Goleta, California. 
electrometer using low-noise coaxial signal cable and a coax-to-triax adapter. The recommended high voltage is $50 \mathrm{~V}$ per revolution of the outer wall of the chamber (1 revolution = approximately $1-\operatorname{mm}$ increase in gap).

\section{Scaler/Ratemeter}

The Bicron scaler/ratemeter(a) is a microprocessor-controlled, standalone counter with a seven-decade light-enitting diode (LED) display. This model features a crystal-controlled time base, preset time, and preset count modes, including integral count, count rate, and elapsed time. In addition, an internal high-voltage supply is capable of providing 0 to $2000 \mathrm{~V}$ for GM counters. The instrument can operate on $110 \mathrm{~V}(\mathrm{ac})(60 \mathrm{~Hz})$ or on its integral battery supply.

The input/output connectors are both coaxial, with a BNC-type for the signal input and an MHV-type for the high-voltage output.

\section{Battery High-Voltage Power Supply}

The battery high-voltage power supply is a box containing a $300 \mathrm{~V}$ battery. A switch is included to select either "polarity" or an "off" position. A range switch allows selected voltages from 0 to 300 volts in discrete steps of $50 \mathrm{~V}$. At the "zero" voltage setting, probe connectors have been installed to allow for a voltage check underload. The output connector is a coaxial MHV connector.

\section{Charge Checker}

Also included in the instrument set is an electronic test circuit for verifying the stability of the electrometer. A mercury battery is used to charge a polystyrene capacitor. Both of the components are stable and produce a charge that is also quite stable over time. This charge pulse monitors the stability of the electrometer's response.

\section{Procedures}

Operating procedures detailing the description and use of the instruments are included in each instrument set. The procedures are updated several times during the year to clarify and address specific characteristics
(a) Bicron Corporation, Newbury, Ohio. 
of each measurement. Included in the procedures are graphic illustrations of the electrical connections for each instrument.

\section{SECONDARY STANDARD BETA SOURCE SET}

The secondary standard beta source set (referred to as the beta set in this report) consists of three beta-emitting sources and an irradiation apparatus, shown in Figure 3. The set, Model BSS.1, was purchased from Amersham (a) and includes a $2-\mathrm{mCi}(74-\mathrm{MBq}) 90 \mathrm{sr} / 90 \mathrm{Y}$ source, a $0.5-\mathrm{mCi}$ (18.5-MBq) $204 \mathrm{Tl}$ source, and a $14.5-\mathrm{mCi}(536.5-\mathrm{MBq}) 147 \mathrm{Pm}$ source. The sources are secured in a lead pig (for shipping) inside a Department of Transportation (DOT) -7A overpack. For irradiations, a source is removed from the pig using the supplied source handling tool and is secured in the irradiation jig. The shutter of the $j i g$ is controlled using a microprocessor-based controller/timer that is part of the set. Other equipment includes beam-flattening filters, reference-distance rods, a jig stand, and instructions for use. The same set is designed to follow the specifications for the series 1 source set of the International Standardization Organization (ISO) standard on beta dosimetry, ISO 6980 (ISO 1984).

The dose rates of the sources have been determined using a PhysikalischTechnische Bundesanstalt(b) (PTB)-type extrapolation ionization chamber calibrated using a similar beta secondary standard set at PNL, which was calibrated at the PTB and checked under the MQA program between PNL and the NIST. Reference dose rates are taken to be at a depth of $7 \mathrm{mg} / \mathrm{cm}^{2}$ and a distance of $30 \mathrm{~cm}$ from the source for $90 \mathrm{Sr} / 90 \mathrm{Y}$ and $204 \mathrm{Tl}$. The dose rate from $147 \mathrm{Pm}$ is referenced to a depth of $7 \mathrm{mg} / \mathrm{cm}^{2}$ in tissue, at a distance of $20 \mathrm{~cm}$ from the source. The dose rate is also normalized to standard temperature, pressure, and humidity to allow for differences in the delivered dose rate resulting from absorption of the beta particles by air (Pruitt 1985).

(a) Amersham Corporation, Arlington Heights, Illinois.

(b) Physikalisch-Technische Bundesanstalt, Braunschweig, Federal Republic of Germany. 


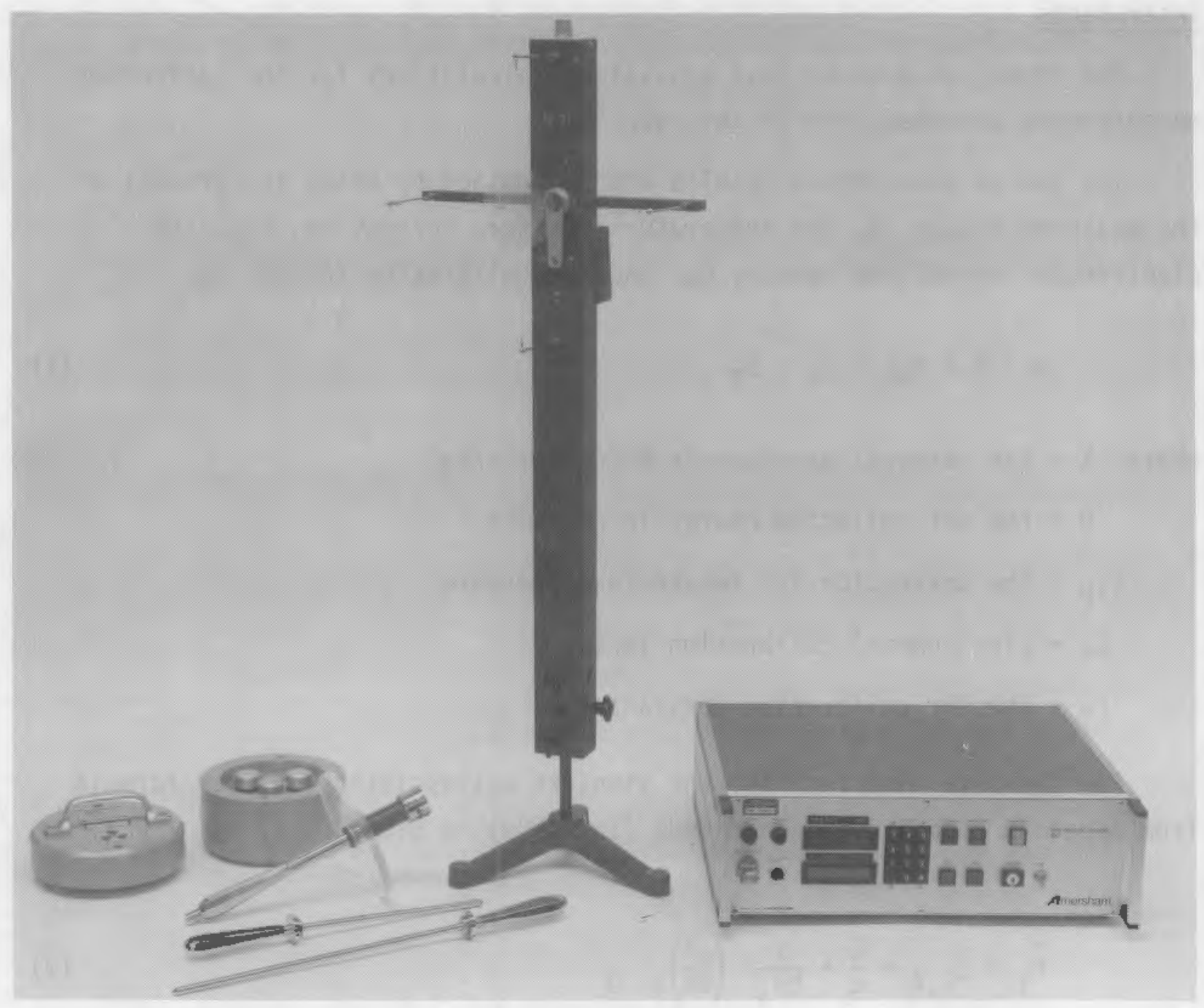

FIGURE 3. DOE Intercomparison Program Secondary Standard Beta Source Set

\section{CALCULATIONS}

Participants in the intercomparison program are requested to deliver a known exposure rate for $x$-ray and photon fields, or a known tissue absorbed dose rate for a beta field, or a known tissue neutron kerma rate for neutron fields. The associated signals are recorded on the supplied data sheets and reported back to PNL. The signals are then used to calculate the appropriate quantity, and ratios of the delivered quantity to the measured result are determined. Those ratios are reported back to the participant in a letter. The calculations used to determine dose and dose equivalent quantities from the measurements and beta source irradiations are given below. 


\section{Instruments}

The signal-to-dose or dose equivalent calculations for the instrument measurements are described in this section.

The photon measurement results are determined by using the product of the measured charge, $Q$, the temperature/pressure correction, $C_{t p}$, the electrometer correction factor, $\mathrm{C}_{\mathbf{e}}$, and the calibration factor, $\mathrm{C}_{\boldsymbol{q}}$.

$$
X=Q \cdot C_{t p} \cdot C_{e} \cdot C_{\gamma}
$$

where $X=$ the integral exposure in $R$ (coulombs $/ \mathrm{kg}$ )

$Q=$ the net collected charge in coulombs

$C_{t p}=$ the correction for temperature/pressure

$\mathrm{C}_{\mathrm{e}}=$ electrometer calibration factor

$C_{\gamma}=$ the PNL calibration constant.

For the beta measurements, the standard extrapolation chamber formula from Appendix C of ISO Standard 6980 (ISO 1984) is used.

$$
\dot{D}_{t}=S_{T, A} \cdot \frac{\bar{W}}{e} \cdot \frac{1}{b \rho_{A}}\left(\frac{d I}{d x}\right)_{x \rightarrow 0}
$$

where $\dot{D}_{t}=$ the absorbed dose rate to tissue at $7 \mathrm{mg} / \mathrm{cm}^{2}$ in rad (Gy)

$S T, A=$ the ratio of the average mass collision stopping powers of tissue and of air

$\overline{\mathrm{W}}=$ The quotient of the mean energy, $w$, expended in dry air per ion formed and the elementary charge, e

$b=$ the effective area of the collecting electrode

$\rho_{A}=$ the density of air at standard temperature and pressure (STP)

$\left(\frac{d I}{d x}\right)_{x \rightarrow 0}=$ the limiting value of the quotient of the corrected mean ionization current, I, produced in the chamber by the chamber depth as this chamber depth $x$ approaches 0 . $\left(\frac{d I}{d x}\right)_{x \rightarrow 0}$ is calculated from the slope of the function $I(x)$ 
$I$ = the mean collected ionization currents (corrected to STP conditions) for positive and negative bias voltages.

For the FWT extrapolation chamber, the area of the collecting electrode is $3.14 \mathrm{~cm}^{2}$. The ratio of $\bar{W} / \mathrm{e}=33.85$ (joules $/$ coulomb). The air density, $\rho_{A^{\prime}}$ is $0.001197 \mathrm{~g} / \mathrm{cm}^{2}$ at $22 \mathrm{C}(295 \mathrm{~K})$ and $760 \mathrm{mmHg}(101.3 \mathrm{kPa})$. No further corrections are applied to adjust the signals for effects listed in Appendix C of ISO 6980 (ISO 1984).

The neutron measurements require two detectors: a tissue equivalent plastic ionization chamber for total (gamma plus neutron) kerma and a GM counter for garma kerma. The following calculation for tissue kerma rate is taken from International Comission on Radiation Units and Measurements (ICRU) Report 26, Neutron Dosimetry for Biology and Medicine (1977) and from American Association of Physicists in Medicine (AAPM) Report 7, Protocol for Neutron Beam Dosimetry (1980). The first step is to calculate the response of the tissue equivalent chamber (Equation 3) and GM counter (Equation 4) by:

$$
\begin{aligned}
& \dot{R}_{\mathrm{T}}=\dot{Q} \cdot \mathrm{C}_{\mathrm{T}} \\
& \dot{\mathrm{R}}_{\mathrm{u}}=\dot{\mathrm{N}} \cdot \mathrm{C}_{\mathrm{u}}
\end{aligned}
$$

where $\dot{R}_{T}=$ the response of the tissue equivalent ionization chamber fram neutrons and photons ( $\mathrm{rad} \cdot \mathrm{sec}^{-1}$ )

$\dot{Q}=$ the average current from the tissue equivalent ionization chamber corrected for air density and electrometer calibration (coulomb $\cdot$ sec$^{-1}$ )

$C_{T}=$ the ionization chamber calibration constant (rad $\cdot$ coulomb-1)

$\dot{R}_{u}=$ the response of the GM counter from photons ( $\mathrm{rad} \cdot \mathrm{sec}^{-1}$ )

$\dot{N}=$ the average pulse rate collected using the GM counter (pulses - sec-1)

$C_{u}=$ the $G M$ calibration constant (rad - pulse-1).

In order to calculate a neutron kerma rate to tissue, two assumptions are made about the $G M$ counter. First, response of the $G M$ counter is assumed independent of photon energy (e.g., the number of pulses per roentgen is 
equivalent for photons with different energies over a wide range of energies). The energy response of the counter quoted by the manufacturer is $1.00 * 0.10$ for photons with energies between 0.07 and $2.0 \mathrm{MeV}$.

The second assumption is that the response of the GM counter to neutrons is negligible. Ongoing work at the PTB indicates that the neutron response (pulses per rad, tissue kerma) is less than $2 \%$ of the photon response for small commercially available GM tubes.

The neutron kerma rate in tissue is then calculated by:

$$
\dot{D}_{n}=\left(\dot{R}_{T}-\dot{R}_{U}\right) \cdot \frac{\left(S_{w, g}\right)_{N}}{\left(S_{w, g}\right)_{c}} \cdot \frac{\bar{W}_{N} / e}{\bar{W}_{c} / e} \cdot \frac{K_{N}}{K_{c}} \cdot A_{w c} \cdot f_{t, c}
$$

where $\dot{D}_{n}=$ neutron kerma rate in tissue $\left(\mathrm{rad} \cdot \mathrm{sec}^{-1}\right.$ )

$$
\left(S_{w, g}\right)_{x}=\begin{aligned}
& \text { ionization chamber gas-to-wall kerma conversion factor for the } \\
& \text { secondary charged particles created by the neutron field }
\end{aligned}
$$
$(x=N)$ or by the calibration source $(x=C)$

$\bar{W}_{x} / e=$ average energy required to create an ion pair in the chamber gas by secondary charged particles created by the neutron field $\{x=N)$ or by the calibration source $(x=C)$

$K_{N}=$ neutron kerma factor ratio for ICRU muscle tissue relative to A-150 tissue equivalent (TE) plastic

$K_{C}=$ quotient of mass energy absorption coefficients for ICRU muscle tissue to A-150 TE plastic for the photons from the calibration source

$\begin{aligned} & A_{w C}= \text { attenuation and scattering correction factor for the cali- } \\ & \text { bration source for the TE chamber of equilibrium wall thickness }\end{aligned}$

$f_{t, c}=$ ICRU muscle tissue kerma-to-exposure conversion factor for the photons from the calibration source.

The parameters in the kerma calculation are dependent on the neutron energy spectrum of the neutron field and on the calibration source. Because $137 \mathrm{Cs}$ is the calibration source, the following values have been adopted: 


\begin{tabular}{|c|c|c|}
\hline Parameter & Value & Reference \\
\hline$\left(S_{w, g}\right)_{N}(A-150 / a i r)$ & $\sim 1.17$ & AAPM Report No. 7 \\
\hline$\left(S_{w, g}\right)_{C}(A-150 / a i r)$ & 1.10 & Hubbel1 1982 \\
\hline $\bar{W}_{c} / e$ (air) & $33.85(\mathrm{~J} / \mathrm{C})$ & ICRU No. 311979 \\
\hline $\bar{w}_{N} / e$ & $\sim 35.5(\mathrm{~J} / \mathrm{C})$ & AAPM Report No. 7 \\
\hline$K_{\mathbf{H}}$ & -0.96 & AAPM Report No. 7 \\
\hline$K_{c}(a i r)$ & 1.002 & Hubbel1 1982 \\
\hline $\begin{array}{l}A_{w C}(A-150) \\
\text { (chamber wall }=0.34 \mathrm{~cm})\end{array}$ & 1.026 & Hubbel] 1982 \\
\hline$f_{t}, g$ & 0.961 & Hubbell 1982 \\
\hline
\end{tabular}

\section{Beta Sources}

The delivered doses from the beta sources in the secondary standard beta source set are calculated according to Böhm (1986):

$$
D=\dot{D}_{r} \cdot t \cdot K_{Z} \cdot K_{A} \cdot K_{F}
$$

where $0=$ the delivered dose in $\mathrm{rad}$ (Gy)

$\dot{D}_{r}=$ the reference dose rate at $7 \mathrm{mg} / \mathrm{cm}^{2}$, the reference distance at the reference calibration date

$t=$ the irradiation time

$K_{Z}=$ the exponential decay correction to the source strength $K_{A}=$ the air density correction to the dose because of temperature
and pressure variations

$K_{F}=$ the air density correction to the dose because of humidity

The values of $K_{Z}$ and $K_{F}$ currently adopted for the beta sources are contained in Table 2. In addition, the delivered doses are corrected for variations in air density, $K_{A}$, using the following algorithm from Pruitt (1985):

$$
D=D_{0}\left(1+a x+b x^{2}\right)
$$


where $D=$ reference dose at $22 C(295 \mathrm{~K})$ and 760 torr $(101.3 \mathrm{kPa})$

$D_{0}=$ the delivered dose

$a, b=$ coefficients listed in Table 3

$$
x=1-\rho / \rho_{0}
$$

$\rho=$ air density during the irradiation

$\rho_{0}=$ air density at the reference temperature and pressure.

TABLE 2. Parameters Used to Calculate the Absorbed Dose from the DOE Intercomparison Beta Sources

\begin{tabular}{llc} 
Source & $\mathrm{KZ}$ & $\mathrm{K}_{\mathrm{F}}$ \\
${$\cline { 4 - 5 }$/ 90 \mathrm{Y}} }$ & $\exp \left(-6.66 \times 10^{-5} \mathrm{t}\right)(\mathrm{a})$ & 1.0 \\
$204 \mathrm{Tl}$ & $\exp \left(-5.024 \times 10^{-4} \mathrm{t}\right)$ & 1.0 \\
$147 \mathrm{P}_{\mathrm{m}}$ & $\exp \left(-7.248 \times 10^{-4} \mathrm{t}\right)$ & $1.02 \exp \left(-4.37 \times 10^{-4} \mathrm{RH}\right)(\mathrm{b})$
\end{tabular}

(a) $t$ is time (in days) that has elapsed between the calibration date and the irradiation date.

(b) $\mathrm{RH}$ is the relative humidity in percent.

TABLE 3. Parameters Used to Calculate the Air Density Corrections, $K_{A}$, $D=0_{0}\left(1+a x+b x^{2}\right)$, and $x=1-\rho / \rho_{0}$

\begin{tabular}{|c|c|c|c|c|}
\hline Nuclide & $\begin{array}{c}\text { Nominal Activity } \\
(\mathrm{MBq})\end{array}$ & $\begin{array}{l}\text { Reference Oepth } \\
\left(\mathrm{mg} / \mathrm{cm}^{2}\right) \\
\end{array}$ & a & b \\
\hline${ }_{147}$ & 518 & 7 & 3.54 & 19.79 \\
\hline וד204 & 18.5 & 7 & 0.13 & -0.33 \\
\hline $90 S r+90 Y$ & 74 & 7 & -0.05 & -0.18 \\
\hline
\end{tabular}




\section{MEASUREMENT RESULTS}

During FY 1988, eight laboratories requested the intercomparison instrument sets and two laboratories requested the secondary standard beta set. Six of the participating laboratories using instrument sets performed measurements. The other four participants encountered unforeseen problems with staffing and facility availability and were unable to complete the measurements. Both of the participants using the beta set performed irradiations. However, beta set measurement data had not yet been received at the time of this printing.

The instruments were used to intercompare calibration fields associated with ${ }^{137} \mathrm{Cs}$, 60Co, 239PuBe, 252 Cf, 905r, and filtered x-ray sources.

The results of the photon measurements are sumarized in Table 4 . The average and one standard deviation of the delivered-to-measured exposure rate ratios was $0.99 \pm 0.10$. The results indicate excellent agreement.

The results of the neutron measurements are summarized in Table 5 . The average and one standard deviation of the delivered-to-measured kerma rate ratios was $1.45 \neq 0.55$. As part of the charter of the intercomparison program, an additional neutron measurement technique was tested. This technique is based on the tissue equivalent proportional counter (TEPC). The agreement between the TEPC measurements and the delivered doses was somewhat better than using the TEIC and GM, especially on 252Cf. A TEPC has been used at PNL achieving results of 1.02 for the measured kerma rate to the NIST computed kerma rate. 
TABLE 4. Sumary of Intercomparison Results Using the Air Equivalent Ionization Chamber

\begin{tabular}{|c|c|c|}
\hline Participant & Source & $\begin{array}{c}\text { Ratio } \\
\text { Delivered/Measured }\end{array}$ \\
\hline \multirow[t]{2}{*}{ B } & $60 \mathrm{Co}$ & 0.96 \\
\hline & ${ }^{137} \mathrm{Cs}$ & 0.96 \\
\hline \multirow[t]{3}{*}{ D } & ${ }^{137} \mathrm{Cs}$ & 0.88 \\
\hline & ${ }^{137} \mathrm{Cs}$ & 0.96 \\
\hline & ${ }^{137} \mathrm{Cs}$ & 1.17 \\
\hline \multirow[t]{2}{*}{ H } & $137 \mathrm{Cs}$ & 1.00 \\
\hline & Standa & $\begin{array}{l}\text { Average } \\
\text { viation }\end{array}$ \\
\hline
\end{tabular}

TABLE 5. Sumnary of Intercomparison Results for Neutron Kerma Rate Measurements

\begin{tabular}{|c|c|c|c|}
\hline Participant & Source & Technique & $\begin{array}{c}\text { Ratio } \\
\text { Delivered/Measured }\end{array}$ \\
\hline B & $252 \mathrm{Cf}$ & TEIC/GM & 2.50 \\
\hline \multirow[t]{6}{*}{$E$} & PuBe & TEIC/GM & 1.16 \\
\hline & PuBe & TEPC & 1.11 \\
\hline & PuBe & TEPC & 1.52 \\
\hline & $252 \mathrm{Cf}$ & TEIC/GM & 1.40 \\
\hline & $252 \mathrm{Cf}$ & TEPC & $\underline{1.02}$ \\
\hline & & One Standar & $\begin{array}{l}\text { Average } \\
\text { viation }\end{array}$ \\
\hline
\end{tabular}


Two participants used the FHT extrapolation chamber to measure the absorbed dose rate from a $90 \mathrm{Sr}$ source; however, only one participant's results are reported (Table 6$)$. The agreement was very good $(1.03 * 0.04)$ showing that for high-level beta sources ( 9 to $10 \mathrm{rad} / \mathrm{h}$ ), this small chamber is adequate for intercomparisons.

One participant performed the first $x$-ray intercomparison measurements in this program (Table 7). The H-150 intercomparison ratio was 0.99 and the $M-30$ was 1.01 .

TABLE 6. Summary of Intercomparison Measurements Using the FHT Extrapolation Chamber

$\begin{array}{ccc}\text { Participant } & \text { Source } & \begin{array}{c}\text { Ratio } \\ \text { Delivered/Measured }\end{array} \\ 90 \mathrm{Sr} & 1.02\end{array}$

TABLE 7. Sumary of Intercomparison Measurements on X-Ray Sources

$\begin{array}{ccc}\text { Participant } & \text { Source } & \begin{array}{c}\text { Ratio } \\ \text { Delivered/Measured }\end{array} \\ \text { H } & \text { H-150 } & 0.99 \\ & \text { M-30 } & 1.01\end{array}$




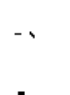




\section{PROGRAM PROBLEMS AND IMPROVEMENTS}

Three minor problems were encountered during the operation of the program during this fiscal year: 1) the modification of the GM counters makes the use of the counters too complex and decreases the precision of the measurement technique, 2) several times electronic noise associated with the electrometer prohibited accurate measurements of low output sources, and 3) the volume of the small extrapolation chamber is too small to precisely measure the dose rates from low output sources.

The GM counters were modified for use with the Bicron scalers by removing the internal preamps from the bases of the counters. This modification was made because the scaler, which provided the high voltage as well, did not have the power to supply voltage to the preamplifier in the counter. The modified counters are susceptible to cable length and dead time corrections under this configuration, but the technique still works and did allow for the use of a compact, fully-contained system within the instrument set. The precision of measurements suffered from this modification, however, and the counters had to be calibrated at rates that matched the rates encountered in the neutron fields. To correct the problem, the preamps will be placed back in the GM counters and a separate high voltage supply and timer/counter will be used.

Electronic noise consists of spurious signals caused by small breaks in the signal cables, irregularities in the ion chambers and stray fields that affect the collecting electrode and/or the collecting capacitor within the electrometer. Electronic noise is not usually a problem and is accounted for by using the two-polarity measurement technique. However, for low output sources, the electronic noise may be so large compared to the signal from radiation events in the detector that that signal may be masked by statistical deviations of the electronic noise. To improve the situation, signal cables within the instrument sets will be replaced twice during the year, or when kinks in the cables are visible. In addition, shorter cables will be supplied in the instrument sets to reduce the detector/cable capacitance. Finally, over the next few years, the Keithley 614 electrometers will be replaced with Keithley 35617 electrometers. The 35617 electrometer is a specially configured electrometer used for low-current dosimetry applications. 1t exhibits inherently less noise. 
The small extrapolation chamber was used successfully to measure the dose from a high output $90 \mathrm{Sr}$ source this year. However, the chamber is too small to measure the dose from a low output $204 \mathrm{Tl}$ source (or any low output source), without the use of heroic measures. It will be recompended that the Small FWT extrapolation chambers be replaced with the larger PTW extrapolation chambers in the future.

The program was improved in two ways this year. Three DOE sites were visited this year and the intercomparison measurements were overseen by the intercomparison program manager. In addition, measurements of neutron sources were performed using the TEPC system.

The site visits were very important for establishing communication links between calibrations personnel in the DOE community. In addition, each of the calibration configurations was discussed with the responsible individuals and suggestions made to improve the accuracy and precision of calibration irradiations.

The TEPC system exhibited good agreement with the TEIC system when used on PuBe neutron sources. When used on $252 \mathrm{Cf}$ sources, the TEPC gave results that were much closer to the expected neutron dose equivalent rates. It will be recommended in the future to include a TEPC system as an additional instrument set to be available for those laboratories that have neutron calibration sources. 


\section{CONCLUSIONS}

The program continues to benefit the DOE community by improving radiological calibrations. The intercomparison sets allow comparison of radiological calibration sources to NIST standards. Also, because the reference sources for calibrating the intercomparison instruments are the same as the DOELAP calibration sources, the calibrations are further linked to DOELAP and dosimeter calibrations.

The site visits are beneficial because PNL acts as a central contact for calibration problems and solutions from all the DOE sites. The solutions to calibration problems are disseminated through informal commuications to those sites experiencing problems. 


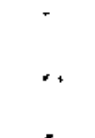




\section{REFERENCES}

American Association of Physicists in Medicine (AAPM). 1980. Protocol for Neutron Beom Dosimetry. AAPM Report No. 7. American Institute of Physics, New York.

Böhm, J. 1986. The Notional Primary Standard of the PTB for Realizing the Unit of the Observed Dose Rote to Tissue for Beta Rodiation. PhysikalischTechnische Bundesanstalt (PTB) Report Bericht Dos-13. ISSN 0172-7095. Physikalisch-Technische Bundesanstalt, Braunschweig, West Germany.

Hubbel1, J. H. 1982. "Photon Mass Attenuation and Energy Absorption Coefficients from $1 \mathrm{keV}$ and $20 \mathrm{MeV}$." Int. J. of Appl. Rodiat. ond Isot. $33(11): 1269-1290$.

International Commission on Radiation Units and Measurements (ICRU). 1977. Neutron Dosimetry for Biology and Medicine. ICRU Report No. 26, International Comission on Radiation Units and Measurenents, Hashington, D.C.

International Commission on Radiation Units and Measurements (ICRU). 1979. Averoge Energy Required to Produce on Ion Pair. ICRU Report Ho. 31, International Commission on Radiation Units and Measurements, Washington, D.C.

International Standardization Organization (ISO). 1984. Reference Beto Rodiotions for Colibrating Dosemeters and Doserotemeters and for Deter-mining Their Response os a Function of Beto Rodiation Energy. ISO 6980-1984(E), International Organization for Standardization, Geneva.

Pruitt, J. S. 1985. "The Effect of Altitude on Beta Ray Source Calibrations." Rodiation Protection Dosimetry. 11(3):151-157. 
•

.

. 


\section{DISTRIBUTION}

No. of

Copies

\section{OFFSITE}

10 DOE/Office of Scientific and Technical Information

DOE Headquarters

R. W. Barber

Office of Safety Compliance Division of Compliance Programs

U.S. Department of Energy, EH-342

Washington, DC 20545

C. N. Borgstrom

Office of NEPA Project Assistance

U.S. Department of Energy, EH-25

Washington, DC 20545

R. Bowser

Office of Quality Programs

U.S. Department of Energy, EH-322

Washington, DC 20545

E. Branagan

Office of Safety Appraisals

Division of Nuclear Safety Technology

U.S. Department of Energy, EH-332

Washington, DC 20545

K. P. Ferlic

Office of Safety Policy and Standards

U.S. Department of Energy

Washington, DC 20545
No. of

Copies

J. E. Fitzgerald, Jr.

Office of Safety Policy and Standards

U.S. Department of Energy, EH-35

Washington, DC 20545

J. P. Knight, Acting Director Office of Safety Appraisals

U.S. Department of Energy, EH-32

Washington, DC 20545

R. S. Scott

Office of Environmental Audit

U.S. Department of Energy, EH-24

Washington, DC 20545

R. W. Starostecki, Deputy

Assistant Secretary for Safety, Hea]th, and Quality Assurance

U.S. Department of Energy, EH-30

Washington, DC 20545

F. Tooper

Office of Safety Policy and Standards,

Division of Operational Standards and Analysis

U.S. Department of Energy, EG-352

Washington, DC 20545

J. C. Tseng, Acting Director

Office of Environmental Guidance and Compliance

U.S. Department of Energy, EH-23

Washington, DC 20585 
No. of

Copies

F. Volpe

Office of Environmental Policy and Standards,

Division of Facility Standards and Applied Research

U.S. Department of Energy, EH-351

Washington, DC 20545

E. R. Williams

Office of Environmental Analysis

U.S. Department of Energy, EH-22

Washington, DC 20545

DOE Albuquerque Operations office

R. E. Alexander

Pantex Plant

Mason \& Hanger--Silas Mason Co., Inc.

P.0. Box 30020

Amarillo, TX 79177

C. H. Applegate

General Electric Company

P.0. Box 11508

St. Petersburg, FL 33733

R. A. Burkhart

General Electric Company

7887 Bryan Dairy Road

P.0. Box 2908

Largo, FL 34294

W. D. Burnett

DOE Sandia National Laboratories

Mail Code 3312, B1dg. 8619

P.0. Box 2800

A1buquerque, NM 87115

A. C. Collins

The Bendix Corporation

P.0. Box 1159

Dept. 442, Maj1 Stop ME39

Kansas City, MO 64141
No. of

Copies

J. Haynie

Los Alamos National Laboratory

MS P229

Los A7amos, NM 87545

E. L. Headrick

Lovelace, ITRI

P.0. Box 5890

A1buquerque, NM 87185

C. Pohl

Lovelace, ITRl

P.0. $80 \times 5890$

Albuquerque, NM 87185

R. G. Stafford

Los Alamos National Laboratory, MS E584

P.0. $80 \times 1663$

Los Alamos, NM 87545

J. G. Themelis

U.S. Department of Energy

Albuquerque Operations Office

P.0. Box 5400

Albuquerque, NM 87115

J. J. Thompson

Lovelace ITRI

P.0. Box 5890

Albuquerque, NM 87185

DOE Chicago Operations Office

L. V. Coulson'

Fermi National Accelerator Laboratory

P.0. Box 500

Batavia, IL 60510

E. Dolecek

Argonne National Laboratory

9700 S. Cass Ave.

B1dg. 2012H-20

Argonne, IL 66439 
No. of

Copies

J. J. Fennimore

Princeton Plasma Physics Laboratory

P.0. Box 451, Rec \#3

Princeton, NJ 08544

W. S. Freeman

Fermi National Accelerator Laboratory

P.0. Box 500

Batavia, IL 60510

R. A. Mayes

U.S. Department of Energy Chicago Operations office

9800 S. Cass Ave.

Argonne, IL 60439

C. B. Meinhold

Radiological Sciences Division, B1dg. 703M

Brookhaven National Laboratory Upton, NY 11973

D. P. O'Neil

Argonne National Laboratory

9800 S. Cass Ave.

Argonne, IL 60439

DOE Idaho Operations office

J. H. Barry

U.S. Department of Energy

Idaho Operations Office

785 DOE Place

Idaho Falls, ID 83402

R. D. Carlson

U.S. Department of Energy

RESL - CF690

785 DOE Place

Idaho Falls, ID 83402

5 F. M. Cummings

U.S. Department of Energy

Idaho Operations office

785 DOE Place

Idaho Falls, ID 83402-4149
No. of

Copies

F. Jakubowski

EG\&G Idaho, Inc.

P.0. Box 1625, CF -633

Iadho Falls, ID 83415

B. L. Rich

EG\&G Idaho

P.0. Box 1625

Idaho Falls, ID 83401

A. N. Tschaeche

WINCO

MS 5209

P.0. Box 4000

Idaho Falls, ID 83403

DOE Nevada Operations Office

A. E. Bicker

Reynolds Electrical \& Engineering $\mathrm{Co}$., Inc.

P.0. Box 14400

Las Vegas, NY 89114

P. K. Fitzsimmons

U.S. Department of Energy

Nevada Operations Office

P.0. Box 14100

Las Vegas, NV 89114

I. J. Hells

Reynolds Electrical and Engineering $\mathrm{Co}$.

P.0. Box 14400

Las Vegas, NV 98114

DOE Oak Ridge Operations

Office

R. J. Cloutier

Oak Ridge Associated Universities

P.0. Box 117

Oak Ridge, TN 37831-0117 
No. of

Copies

J. J. Davis

Martin Marietta Energy Systems Hobbs Road

Paducah, KY 42001

J. W. Doty

Mound Laboratory

Monsanto Research Corporation

P.0. Box 32

Miamisburg, OH 45342

R. K. Edwards

Martin Marietta Energy Systems Hobbs Road

Paducah, KY 42001

R. E. Halliburton

Oak Ridge National Laboratory

P.0. Box X

Oak Ridge, TN 38731

S. L. Hinnefeld

Westinghouse Materials Co. of Ohio

P.0. Box 398704

Cincinnati, OH 45239

D. B. Howard

U.S. Department of Energy

Oak Ridge Operations office

P.0. Box E

Oak Ridge, TN 37831

S. Jones

Martin Marietta Energy Systems

Portsmouth GDP, P.0. Box 628

Piketon, $\mathrm{OH} 45661$

W. T. Hee

$Y-12$

P.0. Box $Y$

Oak Ridge, TN 37831

D. C. Parzyck

Oak Ridge National Laboratory

P.0. Box 2008

Oak Ridge, TN 37831-6103
No, of

Copies

\author{
S. F. Seltzer \\ Paducah Gaseous Diffusion \\ Plant \\ P.0. Box 1410 \\ Paducah, KY 42001 \\ F. G. VanLoocke \\ RMl Company \\ P.0. Box 579 \\ Ashtabula, $\mathrm{OH} \quad 44004$ \\ E. R. Wagner \\ Portsmouth Gaseous Diffusion \\ Plant \\ Mart in Marietta Energy Systems \\ P.0. Box 628 \\ Piketon, $\mathrm{OH} 45661$ \\ H. D. Whitehead \\ Oak Ridge Gaseous Diffusion \\ Plant \\ P. 0. Box 2003 \\ 0ak Ridge, TN 37831-7403 \\ M. Winegardner \\ Monsanto Research Corp. Mound \\ P.0. Box 32 \\ Miamisburg, OH 45342 \\ DOE San Francisco Operations \\ Office
}

G. W. Campbe11

Lawrence Livermore National Laboratory

P.0. Box 808, MSL382

Livermore, CA 94550

C. Graham

Lawrence Livermore National Laboratory

P.0. Box 5505, L-380

Berke]ey, CA 94550

T. Greenhouse

University of California

Lawrence Berkeley Laboratory

B1dg. 75

Berkeley, CA 94720 
No. of

Copies

T. R. Crites

Lawrence Livermore National Laboratory, L-382

P.0. Box 808

Livermore, CA 94550

J. T. Davis

U.S. Department of Energy

San Francisco Operations office

1333 Broadway

0akl and, CA 94612

R. C. McCall

Stanford Linear Accelerator

P.0. Box 4349

Stanford, CA 94305

R. G. Thomas

Lawrence Berkeley Laboratory

1 Cyclotron Road

Berkeley, CA 94720

D. Trombino

Lawrence Livermore National Laboratory

P.0. Box 5505

Livemore, CA 94550

G. Warren

Stanford Linear Accelerator

P.0. Box 4349

Stanford, CA 94305

D. Wright

Hazards Control Division

Sandia National Laboratory

MS 8263

Livermore, CA 94550

DOE Savannah River Operations

Dffice

D. N. Bridges

U.S. Department of Energy

Savannah River Operations Office

P.0. Box A

Aiken, SC 29801
No. of

Copjes

K. W. Crase

E. I. DuPont de Nemours \& Co.

Savannah River Plant

B1dg. 735A

Aiken, SC 29808

W. C. Reinig

E. I. duPont de Nemours \& Co.

Savannah River Plant

Aiken, SC 29801

EPA Office of Radiation Programs

A. Richardson

U.S. Environmental Protection Agency, ANR-460

401 M Street, SW

Washington, DC 20460

National Center for Devices and Radiological Health

J. C. Villforth

FDA Bureau of Radiological Health

Rockville, MD 20852

National Institute of Standards and Technology

E. H. Eisenhower

National Institute of Standards and Technology

B1dg 245, Rm. C229

Gaithersburg, MD 20899

R. Schwartz

National Institute of Standards and Technology

A-155 Reactor

Quince Orchard \& Clopper Rds.

Gaithersburg, MD 20899

Nuclear Regulatory Commission

R. E. Alexander

U.S. Nuclear Regulatory Commission

Washington, DC 20555 
No. of

Copies

\section{ONSITE}

DOE Richland Operations Office

E. C. Norman

31 Pacific Northwest Laboratory

W. J. Bair

G.W.R. Endres

L. G. Faust

D. M. Fleming
No. of

Copies

J. R. Houston

J. R. Johnson

J. L. Kenoyer

J. C. McDonald (5)

H. K. Murphy (10)

J. M. Selby

K. L. Soldat

Health Physics Department Library

Publishing Coordination

Technical Report Files (5) 